\title{
1. Law of administrative organization of the EU: a regulatory task and mandate for research
}

\section{INTRODUCTION}

In the preface to the third edition of his seminal Deutsches Verwaltungsrecht, Otto Mayer (1846-1924), who laid the main foundations of German administrative law, wrote the famous phrase, 'Verfassungsrecht vergeht, Verwaltungsrecht besteht'. 'This was a provocation in 1924, an outrageous statement barely six years after the collapse of the German monarchies, but it was true in some sense: ${ }^{2}$ the pre-1918 foundations survived the shift from monarchy to republic (some of them until now, interrupted by the real catastrophe of the German Rechtsstaat). In our times, we may be witnesses of a similar non-simultaneous development between constitutional and administrative law, between high politics and the everyday operations of basic public law guarantees and mechanisms, this time in the European Union (EU).

Processes that appear to reveal disintegration come to the fore. Even before the pandemic, the EU has been struggling with a polycrise (Jean-Claude

\footnotetext{
1 ('Constitutions come and go, administrative law persists'); O Mayer, Deutsches Verwaltungsrecht (3rd edn, Duncker \& Humblot 1924). A modern perspective (without quoting Mayer) of this observation is taken by T Ginsburg, 'Written Constitutions and the Administrative State: On the Constitutional Character of Administrative Law' in S Rose-Ackerman and PL Lindseth (eds), Comparative Administrative Law (2nd edn, Edward Elgar 2017) 60, 65f.

Not long ago, the situation was considered to be the reverse: Member States' constitutional law was solid, administrative law was under constant pressure of modification from the EU: C Engel, 'Die Einwirkungen des Europäischen Gemeinschaftsrechts auf das deutsche Verwaltungsrecht' (1992) 25 Die Verwaltung 437, 438.

2 See the reflections by $\mathrm{C}$ Waldhoff, 'Kann das Verfassungsrecht vom Verwaltungsrecht lernen?' in C Franzius, S Lejeune, K von Lewinski, K Meßerschmidt, G Michael, M Rossi, et al (eds), Beharren. Bewegen. Festschrift für Michael Klopefer zum 70. Geburtstag (Duncker \& Humblot 2013) 261, $264 \mathrm{f}$.
} 
Juncker ${ }^{3}$ ): the state debt-crisis is not over yet as its effects are concealed by a propitious development of the world economy and the extensive monetary policy of the European Central Bank. Insurmountable divergences of interest, and ongoing unexpected political uncertainty following from the 2017-18 general election and coalition-building in Germany, one of the core stakeholders in this context, will continue to prevent an agreement on the Eurozone reform for some time. ${ }^{4}$ The migration crisis hits one high water mark of fierce political debate after the other, with individual member states openly opposing the search for European consensus - the humanitarian disaster in the Mediterranean Sea and the deep divide on the issue in European societies notwithstanding. ${ }^{5}$ Member state after member state appears to slide down the slippery slope to autocracy, designated with the dubious term of 'illiberal democracy' but replete with all the well-known ingredients that destroy free speech, the rule of law and democracy. ${ }^{6}$ Who would have thought that Article 7 of the Treaty on European Union (TEU) would have to be triggered so soon? That the European Commission would have to fight against open breaches of the rule of law by means of the infringement procedure under Article 258 of the Treaty on the Functioning of the European Union (TFEU)? The general elections in the Czech Republic and Italy (2017 and 2018, respectively) brought into power governments that campaigned on platforms that were openly hostile to European integration, a result we luckily escaped in the Netherlands and France. Spain struggles to get back on the scene after years of agony. Above all, Brexit is looming large, the most obvious symptom of an apparent disease - so irrational from any standpoint, but so much strived for by a people that chose to put the desire to regain control over everything else. ${ }^{7}$ Every new crisis event appears to bring the EU to the brink of failure; many, if

3 ('Polycrisis'); J-C Juncker, 'Opening Remarks by President Jean-Claude Juncker on the Conclusions of the European Council meeting of 17 and 18 December' (European Parliament Plenary Session, Brussels, 19 January 2016, SPEECH/16/112) http://europa.eu/rapid/press-release_SPEECH-16-112_de.htm, accessed 29 February 2020.

4 M Ruffert, 'The Future of the European Economic and Monetary Union (EMU): Issues of Constitutional Law' in F Bignami (ed), EU Law in Populist Times - Crises and Prospects (Cambridge University Press 2019) 33.

5 D Thym, 'Der neue Geist von Dublin' Frankfurter Allgemeine Zeitung (Frankfurt am Main, 21 June 2018) 6.

6 Cf only KL Scheppele, 'Constitutional Coups in EU Law' in M Adams, A Meuwese and EH Ballin (eds), Constitutionalism and the Rule of Law. Bridging Idealism and Realism (Cambridge University Press 2017) 446. On Poland, see also European Commission press release, 'Opening of Infringement Proceedings' (2 July 2018) IP/18/4341.

7 See the seminal article by P Craig, 'Brexit: A Drama in Six Acts' 41 (2016) European Law Review 447. 
not the majority, of European Council meetings appear to be of an emergency character. The idea of a 'Constitution for Europe', at the heart of the debate in the mid-2000s, appears to be dead.

However, the European apparatus is still working. The European Commission prepares legislative proposals, including in the controversial fields mentioned, and it deploys considerable administrative activity. It issues enormous penalties against the most powerful information technology (IT)-media companies of the world. ${ }^{8}$ It negotiates package deals in controversial regulatory fields, such as the energy and telecommunications markets. ${ }^{9}$ Together with the other institutions, it has built up an impressive supervisory and restructuring capacity in the banking sector. ${ }^{10}$ Meanwhile, there is a proliferation of administrative agencies. The number of decentralized or regulatory agencies in the EU has risen to more than $30,{ }^{11}$ and there is no sign of an end to this remarkable growth. The agencies are vested with more and above all further reaching powers than their predecessors. Academic activity is blossoming as well, the most remarkable illustration being a successful academic project for the codification of the administrative procedure of the EU (an EU equivalent of the US Administrative Procedure Act (APA), EU APA) presented by the Research Network on EU Administrative Law (ReNEUAL). ${ }^{12}$

This academic achievement is most impressive. Although there are few signs currently that the European legislative process will take up the results of the ReNEUAL project, nevertheless, the results provide for the first time common ground to discuss the elements of an administrative procedure of

8 European Commission press release, 'Antitrust: Commission Fines Google $€ 4.34$ Billion for Illegal Practices Regarding Android Mobile Devices to Strengthen Dominance of Google's Search Engine' (18 July 2018) IP/18/4581.

9 European Commission, 'Communication from the Commission to the European Parliament, the Council, the European Economic and Social Committee, the Committee of the Regions and the European Investment Bank, Clean Energy For All Europeans' COM (2016) 860 final.

10 Council Regulation (EU) 1024/2013 of 15 October 2013 conferring specific tasks on the European Central Bank concerning policies relating to the prudential supervision of credit institutions [2013] OJ L287/63; Regulation (EU) 806/2014 of the European Parliament and of the Council of 15 July 2014 establishing uniform rules and a uniform procedure for the resolution of credit institutions and certain investment firms in the framework of a Single Resolution Mechanism and a Single Resolution Fund and amending Regulation (EU) 1093/2010 [2014] OJ L225/1; Intergovernmental Agreement on the Transfer and Mutualisation of Contributions to the Single Resolution Fund, Council Doc 8457/14 of 14 May 2014.

11 Cf Chapter 3, s 2.3.1 in this volume.

12 P Craig, H Hofmann, J-P Schneider and J Ziller (eds), ReNEUAL Model Rules on EU Administrative Procedure (Oxford University Press 2017). 
the EU. ${ }^{13}$ Procedural requirements for rule-making, the conditions for issuing single decisions and of entering into public contracts, the important rules on mutual assistance between authorities as well as the framework for a modern and viable information management of the EU authorities are proposed for codification - drawn from a thorough comparative effort and extending over many if not all fields of EU administrative law. This academic achievement provides conceptual clarity and reduces ambiguities in terminology. It also advances - visible in the result - the level of comparative methodology with respect to administrative law in Europe.

Despite the impressive completeness of the ReNEUAL draft in all procedural issues, it did not address a very prominent field of administrative law - the law of administrative organization. This statement is devoid of any grain of critique; if a project is designed to issue the EU APA, it is not meant to be about administrative organization. However, the need for common ground in the concepts and terminology, rules and principles is as pressing in the field of administrative organization as it is in the field of administrative procedural law. ${ }^{14}$ Just to list a few questions: what is the administrative role of a 'political' Commission post-Lisbon? How can administrative consistency and coherence be preserved if the EU creates a new decentralized/regulatory agency roughly every other year? What about the (democratic) accountability of the EU administrative institutions? What does 'independence' mean in this context? Can administrative federalism work if member states' representatives are dominant on many of the boards of the agencies? What does the participation of third countries mean in other, hybrid institutions, such as common undertakings (not considered as agencies)? It would be both unfair and pretentious to state that there was no research on these questions and the problems around them. On the contrary, there is a high quantity of papers and books, and almost all of these publications are of the highest quality regarding the relevant question addressed. However, it is submitted that - similar to how ReNEUAL addressed the very broad field of administrative procedure(s) - a comprehensive view of administrative organization appears to be necessary. The contemporary researcher in the law of administrative organization is still faced with an unsettled terminology, unclear concepts and, in particular, uncertainties about the

13 The latest text adopted by the European Parliament is the European Parliament resolution of 9 June 2016 for an open, efficient and independent European Union administration (2016) P8_TA(2016)0279. There is no subsequent Commission proposal. The issue is not on the Commission work programme.

14 S Augsberg, 'Agencification der Kommissionsverwaltung' (2016) 1 Europarecht Beiheft 119, 120; cf already at a very early stage, W Kahl, 'Europäisches und nationales Verwaltungsorganisationsrecht. Von der Konfrontation zur Kooperation’ (1996) 29 Die Verwaltung 341. 
core link between administrative and constitutional law which is, in respect of organization, legitimacy. This book aims to fill this lacuna.

As regards method, this study follows a comparative path. The peculiarities of the law of administrative organization within administrative law, its proximity to the constitutional foundation of the relevant entity, whether a state or a supranational organization, hinders an over-simplistic comparative synthesis from member states' law. There were instances in the early phase of European integration when administrative organization was a matter of 'copy and paste' from France, but this was a distinct historical phase. ${ }^{15}$ From where else should the early European communities have drawn their administrative organizational patterns? The three smaller member states? Germany, which had undergone massive destruction not only in the external sense? Italy? Today, such a transfer of structures from a single member state would be flawed, and it can be shown that the institutions do not apply this type of approach. Therefore, it is more useful to choose, as our point of reference for comparison, the only jurisdiction which matches the EU in terms of size, economic power and federal structure: that of the United States of America (USA). There are differences that certainly cannot be overlooked: The EU is not a state; there is no antagonism between President and Congress; there is greater cultural diversity, particularly in linguistic terms. However, it is worth drawing lessons from the US experience, which is a long experience with a heterogeneous administrative apparatus that always has to strive for its constitutional and political balance.

Before we enter the very interesting field of comparative law, some basic conceptual points must be made clear. First, what is meant by the law of administrative organization and why is it so peculiar? Second, what is the state of affairs in EU constitutional and administrative law and the state of the art in the concomitant scholarly efforts?

\section{THE LAW OF ADMINISTRATIVE ORGANIZATION}

\subsection{Administrative Law and Law of Administrative Organization: Peculiarities}

Concentrating upon the term 'law of administrative organization' includes the risk of importing conceptual uncertainties from other debates as well as the concomitant risk of over-simplification when trying to define it irrespective

15 See Chapter 2, s 1 in this volume. 
of a certain jurisdiction. There are, however, plausible elements which allow formulating a workable circumscription of the subject of this book.

To begin with, the idea of having a 'law of administrative organization' operates on the basis that administrative law can be identified as a distinct legal field with its own conceptual framework. This basis is twofold. First, it presupposes that there are activities, powers and organizations that can be summed up under the heading 'administration'. ${ }^{16}$ Within the separation of powers, 'administration' can be taken to include all matters falling within the power of the executive branch that are necessary for the everyday functioning of a state or a supranational entity, with the exception of matters of high politics (waging war, concluding international treaties, giving speeches, and so on). There is no doubt that what is classed as 'the administration' may be different throughout jurisdictions. Whereas in the USA, there is a tradition to designate the whole executive as 'the administration', ${ }^{17}$ the French would distinctly separate the gouvernement from l'administration, and this is reflected in academia where there is a real separation between constitutionnalistes and administrativistes. ${ }^{18}$ However, if the knowledge about these divergent approaches is kept in mind when analysing 'the administration', there is no need to renounce the use of this category.

Second, the concept of administrative law is grounded in the idea that the law governing the administration is different from the legal principles, rules and institutions governing the legal relationships between members of the general public. Ever since Dicey's famous dictum that the idea of administrative law was 'utterly unknown to the law of England, and indeed ... fundamentally inconsistent with our traditions and customs', we know that this assumption is not self-evident. ${ }^{19}$ It is, however, not necessary to adopt the attitude of nineteenth-century France and the developing activity of the Conseil d'État, which defined administrative law exactly as the bundle of special powers

16 Cf J Ziller, 'L'administration' in M Troper and D Chagnollaud (eds), Traité international de droit constitutionnel, tome 3 (Dalloz 2012) 735, 736; KF Gärditz, 'Die Verwaltungsdimension des Lissabon-Vertrags' (2010) 63 Die Öffentliche Verwaltung 452.

17 D Curtin, Executive Power of the European Union (Oxford University Press 2009) 19: 'Lawyers tend to focus, when using the term "executive", on the core political level as opposed to the underlying bureaucracy.'

18 J-F Lachaume, 'La définition du droit administratif' in P Gonod, F Melleray and P Yolka (eds), Traité de droit administratif (Dalloz 2011) 101, $117 \mathrm{ff}$.

19 AV Dicey, Introduction to the Study of the Law of the Constitution (Macmillan 1915) 198f. Cf also Ridge v Baldwin [1964] AC 40 (HL) 72, per Lord Reid: 'We do not have a developed system of administrative law - perhaps because until fairly recently we did not need it.' 
reserved to the $\mathrm{State}^{20}$ (Sonderrecht, as it was later coined in Germany ${ }^{21}$ ) to understand that there are real particularities of public bodies using their rights and competences and that this requires special legal requirements. Currently, even Great Britain has an Administrative Court, and Paul Craig has shown how deeply the guarantees of administrative justice were rooted in English law, ${ }^{22}$ so that there is no need to take the divergences between jurisdictions and legal traditions as a reason (if not pretext) for denying a field designated as 'administrative law'.

The law of administrative organization, though, has an even more complicated position. In legal systems which see administrative law (and the need for it) mainly from the perspective of judicial review, questions of organization are rarely important - unless a basic question of the distribution of competences is at stake which has repercussions on the single citizen or company. In state-centred, traditional administrative jurisdictions, the law of administrative organization may be limited to the description of the existing entities, an exercise that may be neither interesting nor academically rewarding. ${ }^{23}$ However, although courts intervene less often in organizational relationships than elsewhere in the administrative legal system, ${ }^{24}$ there can be no doubt any more that the law of administrative organization is law, not just rules of convenience or custom. ${ }^{25}$ There is an interrelationship between law and organization here. Whereas law needs an organization to be brought into being and effect - in all its functions and facets ${ }^{26}-$ it is law itself creating that organization. ${ }^{27}$ The law

20 On its development, cf in particular P Gonod, Le Conseil d'État et la refondation de la justice administrative (Dalloz 2014).

${ }^{21}$ H-J Wolff and O Bachof, Verwaltungsrecht (Beck 1974) s 22 II c; H-J Wolff, 'Der Unterschied zwischen öffentlichem und privatem Recht'(1950-51) 76 Archiv des öffentlichen Rechts 205, 208.

22 P Craig, UK, EU and Global Administrative Law. Foundations and Challenges (Cambridge University Press 2015) $11 \mathrm{ff}$.

23 E Schmidt-Aßmann, Das allgemeine Verwaltungsrecht als Ordnungsidee (2nd edn, Springer 2004) s5 para 2.

24 Cf. M Burgi, 'Verwaltungsorganisationsrecht - Grundlagen' in D Ehlers and H Pünder (eds), Allgemeines Verwaltungsrecht (15th edn, De Gruyter 2016) s7 para 2.

25 W Krebs, 'Verwaltungsorganisation' in J Isensee and P Kichhof (eds), Handbuch des Staatsrechts: Band V Rechtsquellen, Organisation, Finanzen (3rd edn, CF Müller 2008) s 108 para 33.

${ }_{26}$ M Jestaedt, 'Grundbegriffe des Verwaltungsorganisationsrechts' in W Hoffmann-Riem, E Schmidt-Aßmann, and A Voßkuhle (eds), Grundlagen des Verwaltungsrechts, Band I (2nd edn, CH Beck 2012) s 14 para 2.

27 The matter could be taken further, and the idea of 'organization' could be conceptualized. However, there is no need to do this, as all entities considered in our context are (or have) without any doubt an 'organization' of some sort. On that debate, cf Krebs, 'Verwaltungsorganisation' (n 25) 2; T Groß, 'Die Verwaltungsorganisation als Teil 
of administrative organization is the set of rules, principles and institutions that builds and shapes the organized emanation of a part of the executive power of a state or supranational entity. Insofar as the EU assumes administrative functions, it is up to that supranational organization to develop its own administrative organization, together with a law of administrative organization. ${ }^{28}$

\subsection{Constitutional Law and the Law of Administrative Organization: Political Substance}

The law of administrative organization is complicated for yet another reason. Of all the areas of administrative law, it is the area most affected by the blurred differentiation within the executive, a point that was quickly brushed over in section 2.1. The idea of a law of administrative organization is dependent upon a differentiation, which, on the one hand, is common and considered a truism and, on the other, is evidently wrong. This is the difference between the political and the technical, between constitutional and administrative law.

The political-administrative divide, as shaped by the doctrine of administrative law, is considered one of the central paradigms of legal thinking by one of the leading French administrative law scholars, Jacques Caillosse, ${ }^{29}$ and as common sense or quasi-natural division by other authors. ${ }^{30}$ The divide is deeply rooted in administrative legal scholarship and in administrative scholar-

organisierter Staatlichkeit' in W Hoffmann-Riem, E Schmidt-Aßmann and A Voßkuhle (eds), Grundlagen des Verwaltungsrechts, Band I (2nd edn, CH Beck 2012) s 13 para 4, with references to academic writings in fn 3; T Groß, 'Grundzüge der organisationswissenschaftlichen Diskussion' in E Schmidt-Aßmann, W Hoffmann-Riem, and A Voßkuhle (eds), Verwaltungsorganisationsrecht als Steuerungsressource (Nomos-Verlagsgesellschaft 1997) 139.

${ }_{28}$ Cf again Jestaedt, 'Grundbegriffe des Verwaltungsorganisationsrechts' (n 26) 2 fn 5: 'In dem Maße, in dem etwa die Verwaltungsfunktion von der Europäischen Union wahrgenommen wird, ist es an ihr, eine Verwaltungsorganisation aufzubauen' ('To the extent that an administrative function is performed by the European Union, the latter must establish an administrative organization').

29 Original quotation from J Caillosse, 'Les "principes généraux" de l'organisation administrative' in $\mathrm{P}$ Gonod, $\mathrm{F}$ Melleray and $\mathrm{P}$ Yolka (eds), Traité de droit administratif (Dalloz 2011) 149, 155: 'N'ayons pas peur des mots: la division opérée entre le politique et l'administratif constitue l'un des paradigmes de la pensée juridique, telle qu'elle est mise en forme dans la doctrine de droit administratif' ('Let us not be afraid of words: the division between the political and the administrative is one of the paradigms of legal thought, as it is embodied in the doctrine of administrative law').

30 B Mercuzot, Organisation administrative (Editions Eska 2001) para 22. However, see also the sceptical reflections by M Schröder, 'Die Bereiche der Regierung und der Verwaltung' in J Isensee and P Kichhof (eds), Handbuch des Staatsrechts: Band V Rechtsquellen, Organisation, Finanzen (3rd edn, CF Müller 2008) s 106 paras 29ff. 
ship in genera ${ }^{31}$ - politicians must remain politicians, bureaucrats must remain bureaucrats..$^{32}$ Beyond academic recognition, the divide finds general acceptance in the practice of the European Commission: 'The European Commission has a unique governance system, with a clear distinction between political and administrative oversight structures and well-defined lines of responsibility and financial accountability. ${ }^{33}$ The divide is not only theoretical, and there are concrete consequences drawn from it, separating political decisions from administrative expertise, insulating the administrative from the political by creating 'independent' entities, formulating criteria for bureaucratic accountability. The result is a clear divide, albeit of complementary ${ }^{34}$ spheres, of politics on one side and administration, designed to execute what politics decided in a neutral manner, on the other. ${ }^{35}$

Empirically, however, we know that the differentiation is flawed in an important respect; so flawed that we could say it is evidently wrong. This is because there are no technicalities which are guaranteed to always remain non-political. Everything that can fail is not only technical/bureaucratic, but political. ${ }^{36}$ If an administrative entity is given the power to intervene in the financial markets when certain risk criteria are fulfilled and the entity adopts too lenient a reading of the criteria because it follows a market-liberal approach on how the financial sector should operate, this is a political matter. ${ }^{37}$ If the courts give administrative agencies a scope of interpretation as to the

31 It can be traced back to M Weber, Wirtschaft und Gesellschaft (5th edn, Mohr Siebeck 1980) 559ff; cf E Peuker, Bürokratie und Demokratie in Europa (Mohr Siebeck 2011) 209ff.

32 H Dreier, Hierarchische Verwaltung im demokratischen Staat (Mohr Siebeck 1991) 147: 'für das Verhältnis Gesetzgeber - Verwaltung erfordert das klare normative Vorgaben und eine ebenso klare Trennung zwischen Politik und Bürokratie. Politiker müssen Politiker, Bürokraten müssen Bürokraten bleiben' ('for the relationship between legislator and administration this requires clear normative guidelines and an equally clear separation between politics and bureaucracy. Politicians must remain politicians, bureaucrats must remain bureaucrats').

33 European Commission, 'Communication to the Commission from President Juncker and First Vice-President Timmermans Governance in the European Commission' C(2017) 6915 final (emphasis added). This passage about governance is not taken up in the respective communication of the Commission led by President von der Leyen (European Commission, 'Communication from the President to the Commission. The Working Methods of the European Commission' P(2019) 2).

34 Curtin, Executive Power of the European Union (n 17) $37 \mathrm{ff}$.

35 Caillosse, 'Les "principes généraux" de l'organisation administrative' (n 29) 155.

36 T Groß, 'Ist die Wirtschaftskrise ein Katalysator für das Entstehen unabhängiger Behörden?’ (2014) 47 Die Verwaltung 197, 207.

37 Cf the discussion around Case C-270/12 UKv Parliament and Council-ESMA [2014] ECLI:EU:C:2014:18 in Chapter 4, s 2.3.1 in this volume. 
content of statutory provisions, this goes beyond technical niceties and can hit at the heart of politics. ${ }^{38}$ These short examples drawn from current academic and political discussions reveal a tension that is pertinent throughout this book. A theoretical assumption is needed to uphold the subject and its foundations, but it is under attack from the empirical side at all times.

Another tension related to constitutional law lies in the absence of constitutional norms governing administrative issues; this absence appears in all jurisdictions. The 'hole in the constitution' is proverbial. ${ }^{39}$ It is rare to find a provision such as the French Article 20(2) of the Constitution of 1958, which states that government 'dispose de l'administration' ${ }^{40}$ There are few norms in the German constitution, and in the USA many administrative law scholarship offers are for research into how to fill the hole or holes left by Article II of the Constitution, in particular its sections (2) and (3). ${ }^{41}$ The situation is similar for the EU, where Article 17 TEU establishes the European Commission as the main administrative body, but where a proliferation of administrative agencies takes place without much accompanying text in the Treaties of the European Union (hereafter, the Treaties). This hole is particularly concerning given that the law of administrative organization is known to fulfil key constitutional functions: constituting the rule of law in administrative organization and (democratic) steering of government entities. ${ }^{42}$ The hole contrasts with a clear task.

\subsection{Historical and Political Contingency or 'Law of Organization as a Resource for Regulation'?}

At the national level, the law of administrative organization is usually not shaped by rational criteria or administrative needs. More than is the case with

38 The debate in the USA around Chevron USA Inc $v$ Natural Resources Defense Council Inc 467 United States Reports 837 [1984] (Supreme Court of the United States) is illustrative.

39 JL Mashaw, Creating the Administrative Constitution (Yale University Press 2012) 10, 29ff; WF Willoughby, An Introduction to the Study of Government in Modern States (The Century Co 1919) 242f. Cf s 3.1 in this chapter.

40 ('has the administration at its disposal'); M Ruffert, 'The constitutional basis of EU administrative law' in S Rose-Ackerman, P Lindseth, and B Emerson (eds), Comparative Administrative Law (2nd edn, Edward Elgar Publishing 2017) 667. However, see the enumeration of constitutional provisions from Portugal, Spain, Slovenia and Finland in Ziller, 'L'administration' (n 16) 736.

${ }_{41}$ Cf Chapter 3, s 3.2 in this volume.

42 On the functions of the law of administrative organization ef GF Schuppert, 'Verwaltungsorganisation als Steuerungsfaktor' in W Hoffmann-Riem, E Schmidt-Aßmann and A Voßkuhle (eds), Grundlagen des Verwaltungsrechts, Band I (2nd edn, CH Beck 2012) vol 1, s 16 paras $2 \mathrm{ff}$. 
administrative law in general, the law of administrative organization is subject to historical and political contingencies. In France, the centralized structure built and rationalized ever since the Revolution of 1789 persists. ${ }^{43}$ In Germany, structures are duplicated and multiplied by federalist traditions dating back to the Prussian reforms of 1810 , and a strong local government tracing back to the Middle Ages. ${ }^{44}$ In the USA, many structures perpetuate the rise of administrative power that was galvanized by the 'New Deal' ${ }^{45}$ Also, these historical and political contingencies persist at the EU level, for example the cabinet structure in the European Commission. The EU is old enough to have a distinct geology in its foundations with different layers and deposits. ${ }^{46}$

The view that the organization of the administration can be a tool or resource for assisting the performance of an entity is relatively new. Institutional choice is now considered part of policy choice. The political actors may choose a particular form of organization to improve an entity's performance. ${ }^{47}$ At the national level, this may include instances of privatization. This new perspective carries a further element of non-synchronous phenomena into the law of administrative organization. Historically or politically contingent layers of administrative organization may coexist with deliberately and rationally constructed layers of administrative organization. The layers may be interrelated and diffuse, as not everything that is historically or politically contingent must be irrational and not everything that is constructed in a deliberate way is able to reach the desired level of rationality. Unity of the administration is even harder to achieve in this regard. ${ }^{48}$

43 Chapter 3, s 1.2.1 in this volume.

44 Chapter 3, s 1.3.1 in this volume.

45 DR Ernst, Tocqueville's Nightmare: The Administrative State Emerges in America 1900-1940 (Oxford University Press 2014); O Lepsius, Verwaltungsrecht unter dem Common Law (Mohr Siebeck 1997) 184ff.

46 Curtin, Executive Power of the European Union (n 17) 177.

47 Schuppert, 'Verwaltungsorganisation als Steuerungsfaktor' (n 42) vol 1, 174ff. See generally, K König, 'Konzepte der Verwaltungsorganisation' (2006) 97 Verwaltungsarchiv 482.

48 On that aim Dreier, Hierarchische Verwaltung im demokratischen Staat (n 32) 2; Krebs, 'Verwaltungsorganisation' (n 25) 28. 


\section{THE INTERCONNECTED NATURE OF THE EUROPEAN UNION: MULTILEVEL CONSTITUTIONALISM AND INTEGRATED ADMINISTRATION}

\subsection{Level of Development and Limits of European Constitutional Law: The Achievements of Multilevel Constitutionalism}

The hole in the constitution would be even greater for the EU if there was no constitution at all. All administrative structures to be discussed in this book would just be external extensions of the member states to organize their cooperation with each other. The European Commission and the agencies would be institutionalized knots or hubs to achieve better cooperation, but nothing more. Without a constitution, to talk of supranational institutions would be highly inaccurate.

The question of whether the EU had such a constitutional basis was at the core of the debate throughout the evolution of EU law over the past 25 or more years, and it has just come to a halt. The debate accompanied the protracted treaty reforms, from the Single European Act (1986) onwards: the Treaty of Maastricht (1993), the Treaty of Amsterdam (1999) and the Treaty of Nice (2003) ending up in the formal process of constitution making, which failed with the Dutch and French referenda of 2005, but was preserved in its substance in the Treaty of Lisbon (2009). ${ }^{49}$ As a consequence, there is broad consensus on a constitutional basis of the EU, albeit with different perspectives as to the content and meaning of that basis.

The European Court of Justice (ECJ) is particularly explicit, as - in its famous opinion on the accession of the EU to the European Court of Human Rights (ECHR), which is not subject to great criticism in the passage to be quoted - it underlines 'The fact that the EU has a new kind of legal order, the nature of which is peculiar to the EU, its own constitutional framework and founding principles, a particularly sophisticated institutional structure and a full set of legal rules to ensure its operation.' ${ }^{50}$ The conviction that the EU has its own constitutional framework was foreshadowed in earlier decisions of the ECJ and is shared by many, if not the majority, of authors. ${ }^{51}$ It follows

49 Cf the description by R Schütze, European Constitutional Law (2nd edn, Cambridge University Press 2016) $20 \mathrm{ff}$.

50 Opinion 2/13 [2014] ECLI:EU:C:2014:2454, para 158 (emphasis added).

51 See the seminal opinion of the Opinion of the Court of 14 December 1991 [1991] ECR I-06079, para 21. From academic writing: Schütze, European Constitutional Law (n 49); A Peters, Elemente einer Theorie der Verfassung Europas (Duncker \& Humblot 2001); PM Huber, 'Europäisches und nationales Verfassungsrecht' in 
the insight that the idea of constitutionalism may be transferred beyond the State, despite historical experience which links the idea of constitutionalism to the concept of the modern state. This is all the easier with the ever-growing textual basis of the EU constitution which currently contains a charter of fundamental rights, a catalogue of competences, basic constitutional principles and a sophisticated institutional framework. ${ }^{52}$ The controversy is not as fierce as it used to be, and it is certainly less agitated then the parallel discussion on the constitutionalization of the international community. ${ }^{53}$ Problems arise primarily in the field of legitimacy of power. ${ }^{54}$

Where authors continue to be opposed to this consensus, there is at least clarity of positions and arguments. Some put particular stress on the inherent link between constitution and state and the notion of sovereignty. ${ }^{55}$ They emphasize the difference between a constitution and a treaty, and search for a constitutional moment when the pouvoir constituant exercises its creative power. They seek a given community, a people, or, at least, a communicative collective that shapes the constitution. ${ }^{56}$ An interesting variant of this view has been developed by Peter Lindseth, who underlines the dichotomy between 'constitutional' and 'administrative'. ${ }^{57}$ The supranational construction of European integration is viewed as a perpetuation of the rise of the administrative State since the nineteenth century: administrative tasks that cannot be resolved satisfactorily at the national level are referred to a supranational

Veröffentlichungen der Vereinigung der Deutschen Staatsrechtslehrer (ed), Die deutsche Staatsrechtslehre in der Zeit des Nationalsozialismus. Europäisches und nationales Verfassungsrecht. Der Staat als Wirtschaftssubjekt und Auftraggeber (De Gruyter 2001) 194, 199ff.

52 Cf the presentation by A von Bogdandy, 'Founding Principles' in A von Bogdandy and J Bast (eds), Principles of European Constitutional Law (2nd edn, Hart 2010) 11 .

53 On this issue cf only $\mathrm{S}$ Kadelbach and $\mathrm{T}$ Kleinlein, 'International Law a Constitution for Mankind? An Attempt at a Re-appraisal with an Analysis of Constitutional Principles' (2007) 50 German Yearbook of International Law 303.

54 A Kocharov, Republican Europe (Hart 2017) 15f.

55 D Grimm, 'Wer ist souverän in der Europäischen Union?' in D Grimm (ed), Die Zukunft der Verfassung II: Auswirkungen von Europäisierung und Globalisierung (Suhrkamp 2012) 275.

56 P Lindseth, 'Equilibrium, Demoi-cracy, and Delegation in the Crisis of European integration' (2014) 15 German Law Journal 529, 533.

57 Primarily, P Lindseth, Power and Legitimacy (Oxford University Press 2010), and P Lindseth, 'Democratic Legitimacy and the Administrative Character of Supranationalism: The Example of the European Community' (1999) 99 Columbia Law Review 628. 
administrative level. ${ }^{58}$ This level is described as highly institutionalized but not constitutionalized as it lacks the aforementioned central qualities: there is neither a constitutional moment of the EU nor a communicative collective - just a structure for administrative cooperation. ${ }^{59}$ Although the German Bundesverfassungsgericht (Federal Constitutional Court) accepts the constitutional nature of the EU as a matter of principle - in its judgment on the Treaty of Lisbon - it designates the member states as 'the constituted primary political area of their respective polities' and excludes some policy fields from the grasp of EU power. ${ }^{60}$

To understand the debate on the constitutional theory of the EU, it is necessary to have an appreciation of the federal nature of European constitutionalism. The composite character of the EU is obvious, the constitutive role of the member states cannot be denied. Consequently, scholars are in continuous search of the correct federalist classification of the EU, be it in diachronic comparison with the early USA, ${ }^{61}$ or along the scale of confederation to federation which is drawn from the German historical perspective.$^{62}$ It is along this line of thought that the Federal Constitutional Court (FCC) accepts the term Staatenverbund as a concept to describe the EU's constitutional structure as 'a close long-term association of states'. ${ }^{63}$ This concept is not so distant from a scholarly line of argumentation that activates the idea of multilevel constitutionalism and understands the EU as a polity created by the Treaties as its con-

58 P Lindseth, 'Supranational Organizations' in I Hurd, I Johnstone, and J Katz Cogan (eds), Oxford Handbook of International Organizations (Oxford University Press 2016) 152, $159 \mathrm{ff}$.

59 P Lindseth, "Between the "Real" and the "Right": Explorations Along the Institutional-Constitutional Frontier' in M Adams, A Meuwese, and EH Ballin (eds), Constitutionalism and the Rule of Law. Bridging Idealism and Realism (Cambridge University Press 2017) 60, 78ff.

${ }^{60}$ Lissabon, $2 B v E$ 2/08 - $2 B v E 5 / 08$ - 2 BvR 1010/08 - 2 BvR 1022/08 - 2 BvR 1259/08 - $2 B v R$ 182/09, 123 BVerfGE 267 (Bundesverfassungsgericht, 30 June 2009), para $250 \mathrm{ff}$ and 301 .

${ }_{61}$ R Schütze, From Dual to Cooperative Federalism: The Changing Structure of European Law (Oxford University Press 2009) 75ff; Schütze, European Constitutional Law (n 49) 59ff.

${ }^{62}$ Cf. the seminal paper by S Oeter, 'Souveränität und Demokratie als Probleme in der "Verfassungsentwicklung" der Europäischen Union. Fragen aus Verfassungstheorie und Verfassungsgeschichte an die deutsche Debatte um Souveränität, Demokratie und die Verteilung politischer Verantwortung im geeinten Europa' (1995) 55 Heidelberg Journal of International Law 659.

63 Lissabon, $2 B v E$ 2/08 - 2 BvE 5/08 - 2 BvR 1010/08 - 2 BvR 1022/08 - 2 BvR $1259 / 08$ - $2 B v R 182 / 09$ (n 60), para 229. 
stitution (Verfassungsverbund).$^{64}$ Multilevel constitutionalism is aware of the continuing constitutional importance of the member states. It does not purport to create or justify a 'super-state', but underlines the complementary links between the national and supranational constitutions. ${ }^{65}$ The only constitutional moment is replaced by a process of continuous constitutionalization, ${ }^{66}$ and the presumed obstacles to transnational communication are seen as exaggerated. The terminological debate came to an end at least in Germany when the FCC reconciled the concepts: 'The European Union is an association of sovereign states (Staatenverbund), of constitutions (Verfassungsverbund), of administrations (Verwaltungsverbund) and of courts (Rechtsprechungsverbund). ${ }^{67}$

This statement may be eclectic in its conceptual approach, but it is convincing in the recognition of some constitutional basis of the EU beyond the member states. An association of constitutions (Verfassungsverbund) is a constitutional construction. This idea of a common constitutional framework, composed of the Treaties and complementary national constitutional provisions, offers sound explanations to phenomena which cannot be properly explained (and conceived in their complexity) by a purely cooperative or administrative law perspective of EU law and its operation. ${ }^{68}$ The primacy of EU law with respect to national law (subject to limitations in very exceptional cases ${ }^{69}$ ) enables EU law principles and rules to be binding on administrative law and administrative activity both in the EU institutions and in the member

64 The term was coined by Ingolf Pernice. Cf. I Pernice, 'The Treaty of Lisbon. Multilevel Constitutionalism in Action' (2009) 15 Columbia Journal of European Law 349.

65 I Pernice, 'Bestandssicherheit der Verfassungen: Verfassungsrechtliche Mechanismen zur Wahrung der Verfassungsordnung' in R Bieber and P Widmer (eds), Der europäische Verfassungsraum (Schulthess 1995) 235, 261ff; I Pernice, 'Europäisches und nationales Verfassungsrecht' (2001) 60 Veröffentlichungen der Vereinigung der Deutschen Staatsrechtslehrer 148, 160ff.

66 Peters, Elemente einer Theorie der Verfassung Europas (n 51) $360 \mathrm{ff}$.

67 For the first time in 2 BvR 2735/14, 140 BVerfGE 317 (Bundesverfassungsgericht, 15 December 2015), para 44.

Another line of thought did not develop in the shadow of this eclecticism. Some authors placed the emphasis on the federal links and not on what is federated (constitutions, states, and so on): O Beaud, Théorie de la fédération (Presses Universitaires de France 2007); also C Schönberger, 'Die europäische Union als Bund' (2004) 81 Archiv des öffentlichen Rechts 129. The origins of this idea were attributed to C Schmitt, Verfassungslehre (11th edn, Duncker \& Humblot 2017) 366f, and this perhaps was not helpful.

68 The most unrealistic view appears to be offered by S Haack, 'Demokratie mit Zukunft' (2012) 67 Juristenzeitung 753.

69 Case 6/64 Costa v ENEL [1964] ECR 1253; Honeywell, 2 BvR 2661/06, 126 BVerfGE 286 (Bundesverfassungsgericht, 6 July 2010), para 53. 
states - the latter when implementing EU law. In the text of the Treaties, we can find some explicit provisions to shape the constitutional foundations of EU administrative law. Some of these, which are particularly important for the law of administrative organization, are explained in greater depth, namely, Article 17 TEU on the Commission and Article 298 TFEU on the administration of the EU. ${ }^{70}$ Others deserve to be mentioned here: Articles 197 and 291(1) TFEU on the cooperative framework between the EU and the member states, and most importantly the fundamental rights as laid down in the European Charter on Fundamental Rights which contains, in its Article 41, a right to good administration at the core of individual guarantees in administrative matters. ${ }^{71}$ Finally, the concept of multilevel constitutionalism with all its different nuances is also capable of providing theoretical guidance in many other new situations the EU is faced with, such as the maintenance of fiscal discipline in the eurozone or the interrelationship of the European Parliament and national parliaments established by Article 12 TEU and the relevant protocols to the Treaties.

\subsection{Level of Development and Limits of European Administrative Law: Integrated Administration as the 'Little Brother' of European Integration?}

Usually, European administrative law is of very little interest to the media. This was not so in summer 2018 when a provision of administrative law became the focus of public debate and dominated a whole European Council meeting. Article 3(1) of Regulation (EU) No 604/2013 - the Dublin-III-Regulation - requires the member states to 'examine any application for international protection by a third-country national or a stateless person who applies on the territory of any one of them, including at the border or in the transit zones. ${ }^{72}$ The high number of migrants making such applications at the Austro-German border became a highly sensitive political issue in Germany, particularly given that Germany is surrounded by EU member states plus Switzerland - all safe havens where migrants could ask for protection before reaching the German border. The German Minister for Home Affairs triggered a debate on whether migrants could be unilaterally sent back to Austria. ${ }^{73}$ The dominant position

\footnotetext{
70 Chapter 3, s 2.1.1 in this volume.

71 Ruffert, 'The constitutional basis of EU administrative law' (n 40) 670ff.

72 Regulation (EU) 604/2013 of the European Parliament and of the Council of 26 June 2013 establishing the criteria and mechanisms for determining the member state responsible for examining an application for international protection lodged in one of the member states by a third-country national or a stateless person [2013] OJ L180/31.

73 On this conflict H-P Welte, 'Die Zurückweisung zur Verhinderung unerlaubter Einreisen im Asylbereich - Einreiseverweigerung' (2018) 11-12 Zeitschrift für Ausländerrecht und Ausländerpolitik 431.
} 
has been that the Dublin-III-procedure, that is, the procedure to find out which country was competent to handle a case, would have to take place in Germany, even if it was known that the subsequent transfer of migrants to other countries would be difficult if not impossible. This state of the law leads to a provision of administrative procedural law becoming a strong pull factor for migrants to engage in a risky trip (to say the least) and to transit countries which are probably less attractive places to begin a new life (secondary migration).

The importance of European administrative law might be illustrated by this example, but awareness about it goes a lot deeper. ${ }^{74}$ It was discovered as a field of research in the 1970s when scholars systematized the general principles of law that were applied by the ECJ as a standard for administrative proceedings in the EU. ${ }^{75}$ In practice, the first fields of application were competition law and the Common Agricultural Policy, and the principles were formulated and applied equally for the (then) European Economic Community (EEC) institutions and the member states' authorities. Principles such as the legality of administrative activity, non-retroactivity and the protection of legitimate expectations were identified, analysed and firmly established, and the principle of proportionality entered many jurisdictions via EEC law of the time. The process of influencing member states' law was termed Europeanization. Some scholars even started to adopt a defensive attitude against such 'intrusions' from Brussels and/or Luxembourg. ${ }^{76}$

General principles of law and Europeanization are not concerned with issues of organization. This changed when scholars became aware of the division of labour between the $\mathrm{E}(\mathrm{E}) \mathrm{C}$ institutions and the member states' authorities in the 1990s. Some fields of administration remained firmly with the European Commission, above all the field of competition. For all other fields, for example, environment, it became clear that the member states were committed to implementing the EU policies themselves, and the ECJ provided a summary

74 Cf only A von Bogdandy, 'Vewaltungsrecht im europäischen Rechtsraum - Perspektiven einer Disziplin' in A von Bogdandy, S Cassese and PM Huber (eds), Handbuch Ius Publicum Europaeum, Band IV Verwaltungsrecht in Europa: Wissenschaft (CF Müller 2011) 57; P Craig, EU Administrative Law (3rd edn, Oxford University Press 2018); J-B Auby and J Dutheil de la Rochère (eds), Traité de droit administratif européen (2nd edn, Bruylant 2014).

75 The key publication is J Schwarze, European Administrative Law (1st revised edn, Sweet \& Maxwell 2006).

${ }_{76}$ A brilliant overview over these processes can be found in the following books: T von Danwitz, Verwaltungsrechtliches System und europäische Integration (Mohr Siebeck 1996); M Brenner, Der Gestaltungsauftrag der Verwaltung in der Europäischen Union (Mohr Siebeck 1996); A Hatje, Die gemeinschaftsrechtliche Steuerung der Wirtschaftsverwaltung (Nomos-Verlagsgesellschaft 1998); S Kadelbach, Allgemeines Verwaltungsrecht unter europäischem Einfluß (Mohr Siebeck 1999). 
rule for the administrative procedures of implementation: if there are common rules of administrative law laid down in a regulation or directive (which was rarely the case, except in customs matters), these rules shall apply. If there are no such rules or if the European rules are incomplete, member states' authorities may apply their national procedural law, but this is subject to two conditions: (1) national legislation must not be applied in a manner which is discriminatory compared to procedures for deciding similar but purely national disputes, and (2) national law must not have the effect of making it virtually impossible to implement European Community regulations. ${ }^{77}$ This rule was sufficient to legally handle the European administrative space for a considerable time because it was complemented by a strict separation between the EU and the member states with regard to judicial review or tortuous liability of administrations.

The next iteration carrying European administrative law further was the discovery of cooperative and network structures in the mid-1990s. ${ }^{78}$ In many administrative areas, the authorities of the member states cooperate with each other, and often the European Commission is included in this cooperation. These cooperative structures were necessary in the completion of the internal market for the licensing of products (for example, food) and services (for example, banking services), but they are by no means limited to the economic area, as the initial example (Dublin III) shows. ${ }^{79}$ In this context, it becomes clear that the law of administrative organization is involved. This involvement is not only visible in rules on authorities' competences, but also in the creation of cooperative entities which are generally designated as agencies. The proliferation of EU agencies is the most pertinent current development in EU

77 Constant jurisprudence since: Joined Cases 205 to 215/82 Deutsche Milchkontor GmbH and others v Federal Republic of Germany [1983] ECR 1983-02633, paras 19ff; Case C-298/96 Oelmühle Hamburg AG and Jb. Schmidt Söhne GmbH \& Co. KG $v$ Bundesanstalt für Landwirtschaft und Ernährung [1998] ECR I-04767 para 24.

78 Well explained by J-P Schneider, 'Regulation and Europeanisation as Key Patterns of Change in Administrative Law' in M Ruffert (ed), The Transformation of Administrative Law in Europe/La mutation du droit administratif en Europe (Sellier 2007) 309, $315 \mathrm{ff}$., referring to the seminal work of G Sydow, Verwaltungskooperation in der Europäischen Union (Mohr Siebeck 2004).

79 Examples: Regulation (EU) 2015/2283 of the European Parliament and of the Council of 25 November 2015 on novel foods, amending Regulation (EU) 1169/2011 of the European Parliament and of the Council and repealing Regulation (EC) 258/97 of the European Parliament and of the Council and Commission Regulation (EC) 1852/2001 [2015] OJ L327/1; Directive 2014/65/EU of the European Parliament and of the Council of 15 May 2014 on markets in financial instruments and amending Directive 2002/92/EC and Directive 2011/61/EU [2014] OJ L173/349. 
administrative law, and its consequences for the EU law of administration are at the heart of this book. ${ }^{80}$

As a consequence, there is common consensus on the existence of an integrated European administration. ${ }^{81}$ The problems - often severe - at the politico-constitutional level notwithstanding; at the everyday level, European integration has reached such an administrative density that the integrated character cannot be denied, but must be analysed. The administrative micro level appears to be further advanced in practice than the constitutional macro level, but it continues to need a sound conceptual basis. As an important consequence, increasingly more administrative law scholars discover EU administrative law and develop it further in the tradition of administrative legal scholarship.

The high water mark of the academic construction of the integrated administration (which already exists in practice) is the current effort of codification. The ReNEUAL has proposed an impressive set of rules that could achieve an enormous clarification and enhanced effectiveness of the EU administration. ${ }^{82}$ It is proposed to be based on Article 298 TFEU which implies that it is mainly designed for the 'direct' administration of EU law by EU authorities (the Commission and the agencies); however, as regards legislation of the EU, its rules can also be declared applicable for the member states implementing EU law. ${ }^{83}$ The ReNEUAL draft comprises six books. The first contains general provisions, that is, definitions of key terms and of the scope of applicability of the rules. The following three books cover very important areas of administrative activity, namely, rule-making, single decision-making and contracts, with procedural rules taken either from the practice of the institutions or from the laws of member states. The procedural rules also draw on sources from outside the EU, as the participatory procedures in rule-making are designed following the notice-and-comment procedure of the APA. The field of mutual assistance (fifth book) is crucial for cooperation in the integrated European administra-

80 Chapter 3, s 2.3 in this volume.

${ }^{81}$ Cf the comprehensive explanation by Peuker, Bürokratie und Demokratie in Europa (n 31) $7 \mathrm{ff}$.

82 Craig et al, ReNEUAL Model Rules on EU Administrative Procedure (n 12). See also the project's website: www.reneual.eu, accessed 29 February 2020.

83 Article I-1 of the draft reads:

Scope of application

(1) These model rules are applicable to all EU authorities when they are implementing Union law through administrative action.

(2) These model rules do not apply to Member States' authorities unless EU sector-specific law renders them applicable.

(3) The model rules of Books V and VI are applicable to Member States' authorities as defined in Articles V-1 and VI-1. 
tion, as the Dublin-III-example again shows. Finally, in the sixth book, the ReNEUAL draft covers new ground and for the first time offers a comprehensive rulebook for information management in the network of the European administration, which goes beyond data protection and its requirements.

Currently, it is unclear whether and when the European institutions will take up the academic proposal made by ReNEUAL. The European Parliament has requested the European Commission to propose a codification of EU administrative law, and the Commission could use the academic achievements in the existing proposal, but there is no sign at the moment that the matter will advance in that direction. ${ }^{84}$ The European Ombudsman is a strong player when it comes to administrative law guarantees for EU citizens, but it is unlikely that this will be the institution to reach a breakthrough in this matter. For our purposes, it is sufficient to state that, with this academic proposal, European administrative law has reached a considerable level of doctrinal progress. However, it still lacks any general provisions on administrative organization.

\section{AIMS AND STRUCTURE OF THE BOOK}

This reflection directly leads to what this book intends to achieve. It is meant to elaborate central elements of a law of administrative organization of the EU using a comparative approach. The book briefly considers the extent to which a basis for an EU law of administrative organization can be found in the law of the member states. However, the main comparative focus shall be between the respective law of the EU and the USA. The key objective is to use this comparative analysis to develop terminology, concepts, institutions and structures that are as clear as possible; that provide for the best administrative legitimacy possible; and that are as systematically consistent as possible. This will complement the ReNEUAL draft in the field of administrative organization. In terms of European integration politics, the aim is to stabilize the further development of the EU in the field of administration by providing a framework of clarity, legitimacy and systematic coherence that might be accepted also by critics of the EU bureaucracy.

The book develops those elements of the law of administrative organization of the EU in three categories: central concepts, in particular with respect to terminology (Chapter 3), administrative legitimacy, mainly referring to mechanisms of control and oversight (Chapter 4), and federal interconnections, that is, the horizontal and vertical aspect of administrative organization (Chapter 5). However, before we can turn to the substantive chapters of the book analysing the elements and presenting the three categories, it is necessary to consider

${ }^{84} \mathrm{Cf}$ s 1 in this chapter. 
what methodological approach ought to be used. The comparative method in administrative law is not new, neither is the use of that method in juxtaposing the USA and the EU and their legal systems. However, methodological soundness requires some preliminary reflections on method. Methodological reflections are relatively rare, the analysis might advance the use of the comparative method in administrative law generally, albeit slightly. Methodological questions are the subject of Chapter 2 . 